\title{
Impacts of Business Strategies on Coffee Production and the Environment
}

\author{
Xiang Li
}

\begin{abstract}
This study analyzes the impacts of business strategies on coffee production and the environment. Company $A$ is used as an example to analyze the impacts of corporate activities and environmental initiatives on the decision-making processes of farmers and their coffee production. Farmer loan support, a proxy of environmental engagement strategy of company $A$, is found to induce the production of shade-grown Arabica coffee rather than sun-grown Robusta coffee. It has been found that integrating environmental sustainability into the business strategy is a win-win business model that benefits both the corporation and the environment. The result indicates that a sustainable business model could help to reduce deforestation, $\mathrm{CO}_{2}$ emissions, and climate change impacts.
\end{abstract}

Index Terms-Environmental sustainability, shade-grown coffee, sun-grown coffee, a win-win business model.

\section{INTRODUCTION}

An increased number of scientists across disciplines have accepted the view that a continuous increase in atmospheric greenhouse emissions is altering the climate of the earth. IPCC (Intergovernmental Panel of Climate Change), which is the most recognized international scientific organization that assesses climate change, indicates that the average global surface temperature for 2081-2100 relative to 1986-2005 could continue to rise by $0.3{ }^{\circ} \mathrm{C}$ to $4.8{ }^{\circ} \mathrm{C}$ in different Representative Concentration Pathway (RCPs) due to an increase in the concentrations of atmospheric greenhouse gases [1]-[7]. Variation in climate can affect climate-sensitive systems such as agriculture and forestry and impact related businesses. Alterations of land-use and selective pattern of cultivation can also affect the concentration of carbon dioxide in the atmosphere, which in turn impacts the climate of the earth.

Among various beverage crops, coffee is one of major and the most traded commercial crops that involve demand, supply and environmental issues. Along with the progress of globalization, coffee culture has spread around the world, making global coffee consumption jump significantly over the past decades. With an increase in coffee demand, the total worldwide coffee production has also increased significantly. In 1971, the total worldwide coffee production was 4663 thousand tonnes. It became 8432 thousand tonnes in 2011 [8]. For many people, coffee is a daily necessity. It is also a trendy drink in many countries.

For many suppliers, coffee popularity implies chances and profits. Globally, at business level, an increased number of companies have started coffee business. They have used a

Manuscript received May 6, 2014; revised July 28, 2014.

Xiang Li is with the Faculty of Law, Politics, \& Economics, Chiba University, Chiba, Japan (e-mail: xiangli22@chiba-u.jp). variety of marketing plans, pricing strategies and packaging tactics to target consumers and to maximize their profits. At farm level, a great number of coffee producers depend on coffee plantations to support their families. An increase in demand for coffee has acted as a motivational sign in influencing the behaviors of coffee producers. The increased level of coffee consumption has also provided new entry coffee producers incentives to start coffee production, inducing intensification of price competition. In most cases, relative market price, descriptions of aroma and origins of coffee products affect the purchasing decisions of consumers.

TABLE I: A COMPARISON OF SUN-GROWN COFFEE WITH SHADE-GROWN COFFEE [9], [10]

\begin{tabular}{|l|l|l|}
\hline & Sun-grown coffee & Shade-grown coffee \\
\hline Growing style & Grown under the sun & $\begin{array}{l}\text { Grown under a shade } \\
\text { canopy }\end{array}$ \\
\hline $\begin{array}{l}\text { Requirements: } \\
\text { chemical } \\
\text { fertilizers }\end{array}$ & More & Less \\
\hline $\begin{array}{l}\text { Yield } \\
\text { kg/beans/ha) }\end{array}$ & Higher & Lower \\
\hline $\begin{array}{l}\text { Caffeine } \\
\text { contents in } \\
\text { coffee beans }\end{array}$ & Higher & $1500-3000$ \\
\hline
\end{tabular}

Generally, market coffee mainly includes two types: shade-grown coffee and sun-grown coffee (Table I) [9], [10]. Traditional shade-grown coffee crop is a plant variety that grows under tree canopies in a forest. Less chemical fertilizer is required to produce this type of coffee [10]. Given the backdrop that the forest where the traditional shade-grown coffee plant is grown has a multi-layered vegetation structure, it usually resembles the characteristics of a natural forest [11]. Sun-grown coffee crop, on the other hand, is a plant variety that grows under the direct sunlight. In order to produce this type of coffee, a large number of trees in the forest have to be cut down to open the canopy. Large quantities of chemical fertilizers also need to be applied to grow this type of coffee crop [10].

Comparatively, sun-grown coffee variety is more tolerate to the direct sun light, fungal diseases, and could yield nearly three times as much as those of shade coffee shrubs (Table I) [9], [10]. Robusta coffee (Coffea canephora) is a representative variety of sun-grown coffee. It yields approximately $2300-4000 \mathrm{~kg} /$ beans/ha [10]. In contrast, Arabica coffee (Coffea arabica) is a shade-grown coffee variety. This variety only yields $1500-3000 \mathrm{~kg} /$ beans/ha [10].

Besides these differences, caffeine contents in two types of coffee beans are also different. In comparison with sun-grown coffee variety, shade-grown coffee beans have a lower level of caffeine contents, ranging from $0.8-1.4 \%$ 
(Table I). This type of coffee is more beneficial to the health.

Cultivation of different types of coffee could have different environmental impacts. Many previous studies have supported the view that the production of shade-grown Arabica coffee is more beneficial to the environment [11]-[17]. It has been found that shade-grown coffee land, compared with other types of crop lands, has acted as an important habitat for wildlife [11]. "up to $2 / 3$ of the bird species in natural forests are found in shade coffee lands compared to less than $1 / 10$ bird species in sun-grown coffee farms" [12]. Comparatively, monoculture styled sun-grown coffee farms house very few animals and plants [13]. These phenomena indicate the complex vegetation structure of a shade coffee forest has a higher ability to maintain its biodiversity over time. Furthermore, deforestation activities accompanying the production of sun-grown coffee also emit excessive carbon dioxide.

Although production of sun-grown Robusta coffee seems to bring more profits to people, the cost from this type of production is too high for the environment and our society to pay. Despite the cultivation of shade-grown Arabica coffee crop is more benign to the environment, the reality is not optimistic. A higher yield and the price increase in sun-grown coffee have provided farmers incentives to shift production from shade-grown Arabica coffee to sun-grown Robusta coffee. Since 1996, the ratio of land used to produce shade-grown coffee, relative to the total land area of coffee cultivation, has fallen by nearly $20 \%$ globally [14].

Coffee, a modern beverage, involves people, business, environment and our society. Worldwide, coffee is cultivated in rain-forest regions. Deforestation activities for the production of sun-grown Robusta coffee in these regions are detrimental to the environment. Implementation of environmental sustainability in business strategies would directly affect the incentives and actions of farmers.

Influenced by environmental movement, corporations in many countries have started environmental engagement and summarized their environmental activities in their Corporate Social Responsibility (CSR) reports in recent years. Though more CSR reports have become accessible to the public, information on realistic effects of their environmental engagement on the environment and their business influences on the prevention of climate change are rarely described in the reports. Furthermore, despite an increased environmental awareness of the public, many consumers still have not noticed how powerful their choices have impacted the decision-making processes of coffee farmers and its cascading effects on the ecosystem and the climate.

Thus, diverting from the previous studies that analyzed the impacts of coffee production on ecosystem from environmental perspective, this paper analyzes the impacts of business strategies on coffee production and the environment from both the environmental perspective and the business perspective. Given the backdrop that shade-grown Arabica coffee has higher quality and is more benign to the environment, this paper uses company $\mathrm{A}$ as an example to analyze the effects of its corporate engagement in environmental activities and assistant programs on the behaviors of coffee farmers and coffee production. Analysis result indicates that environmental engagement and assistant programs of company A could influence the behaviors of farmers and promote the production of shade-grown Arabica coffee. Through its environmental commitment, company A could purchase more environmental friendly Arabica coffee. The more support and purchase of this type of coffee rather than sun-grown Robusta coffee, the more supply of Arabica coffee would become available.

This study demonstrates the influential effects of corporate business strategies on the environment and our society. Environmental engagement of one company could influence the cultivation decisions of farmers, promote the production of environmental friendlier Arabica coffee, and prevent deforestation caused by land conversion for production of sun-grown Robusta coffee. Integrating environmental sustainability into business strategy could reduce the potential emissions of anthropogenic $\mathrm{CO}_{2}$ incurred through the alteration of land use. At the same time, the strategy could also reduce climate change impacts. This study illustrates that environmental friendly business strategy could be a win-win business model that benefits the company and the environment, creating a reinforcing loop that finally contributes to the sustainable development of our society.

\section{MATERIALS AND METHODOLOGY}

Analysis focus of this paper is on business strategies, coffee production and the environment. Company A is used as an example in this study to analyze the inducing impact of its business strategy on the decision-making processes of farmers and the production of shade-grown Arabica coffee that is healthier to the environment. Any corporation that highly values environmental protection would engage in business activities that are environmental friendly. Causal link diagram in Fig. 1 illustrates the analysis logic of this study. As illustrated by polarity sign (+), if environmental commitment of company A has an effect on farmers, more shade-grown Arabica coffee rather than sun-grown Robusta coffee would be produced and becomes available to company A. Given the fact that responses usually take time, time lag exists between causes and effects. "Delay" in Fig. 1 is used to represent time lag. More purchase of shade-grown Arabica coffee would induce more production of this type of coffee, leading to an increase in global production of Arabica coffee (+ polarity sign). The increase in total production of Arabica coffee in turn would further increase the availability of this type of coffee and enable company A to purchase more, creating a reinforcing loop (R) (Fig. 1).

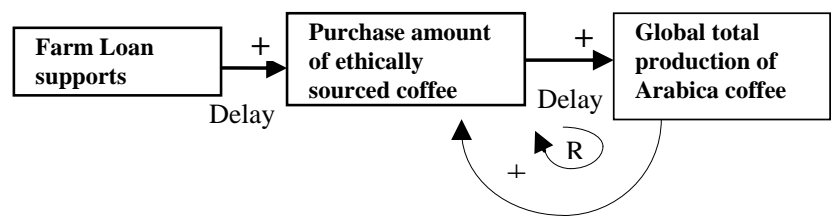

Fig. 1. A causal link diagram that shows the effects of farm loan support on the production of shade-grown Arabica coffee.

In this study, highlighted factors in Fig. 1 are used to analyze the effect of corporate engagement in environmental activities and related assistance on production of environmental soundly high-quality Arabica coffee. 
Company A developed a support model in the farming community system called farmer loan program. The program promotes farming practices that benefit farmers, the environment and the company itself. The program provides financial and technical supports [9].

In cooperation with Conservation International (CI) and SCS Global Services, company A developed Coffee and Farmer Equity (C.A.F.E.) Practices [9], [18]. The C.A.F.E. provides the company the buying guidelines that include more than 200 social, economic and environmental indicators and a set of measurable standards encompassing the areas of product quality, economic accountability, social responsibility, and environmental leadership [18].

In this study, farmer loan support is used as a proxy of environmental engagement strategy of company A. Time series data on farm loan supports and ethically sourced (C.A.F.E. Practice, Fair trade or another externally verified system) coffee purchased by company A over the time period from 2003 to 2013 are collected [9].

The following equation (1) in logarithm form is estimated as:

$$
\ln (E p)=\beta_{0}+\beta_{1} \ln (f l s)
$$

where $E p$ represents the amount of ethically sourced coffee company A has purchased (million kilograms), $f l s$ represents the total amount of farmer loan provided by company $\mathrm{A}$ (million dollars), and $\beta_{0-1}$ indicate estimated coefficients.

\section{Results}

The estimated results are summarized in Table II. In many cases, effects of money support take time to observe. The trend of money supports rather than the support amount in a single year would provide farmers incentives and a sense of security to produce environmental friendly Arabica coffee. Average farmer loan support that is calculated from the previous three years plus the current year is found to have an influence on the purchase amount of ethically sourced coffee in the current year, in line with the agro-economics findings found by $\mathrm{Li}$ [2], [3].

TABLE I: ESTIMATED RESULT OF ENVIRONMENTAL STRATEGY IMPACTS ON THE PURCHASE AMOUNT OF ETHICALLY SOURCED COFFEE

\begin{tabular}{|l|l|}
\hline Explained variable, $\ln (E p)$ & \\
\hline Explanatory variables & $\begin{array}{l}\text { Coefficients } \\
\text { (t-values })\end{array}$ \\
\hline Constant & $2.18(3.3)$ \\
\hline $\ln (f l s)$ & $1.11(4.1)$ \\
\hline R-squared & 0.74 \\
\hline Adjusted R-squared & 0.69 \\
\hline D.W. & 1.91 \\
\hline
\end{tabular}

The analysis result indicates that $1 \%$ increase in farmer loan support could increase the purchase amount of ethically sourced coffee by $1.11 \%$, holding all other variables constant. This result corresponds to the logic described in the causal loop diagram (Fig. 1). An increase in farm loan support would lead to an increase in purchase of ethically sourced coffee above what it would have been, holding all other variables constant (+ polarity). The increased purchase of this type of coffee indicates the fact that more shade-grown Arabica coffee is produced by farmers and become available to purchase. The adjusted R-squared appears to be 0.69 .

Farmer loan support reflects the environmental engagement of company A. The support stabilizes farm income and helps farmers reduce the risks incurred in producing coffee. Given the backdrop that many farmers depend on coffee production to support their families, income stability plays a determining role in guiding the behaviors of farmers [17]. More farmer loan support would induce more farmers to produce more ethically sourced Arabica coffee, which in turn would ensure the stable supply of ethically sourced high-quality Arabica coffee.

Over the years, company A has increased the rate of its annually coffee purchase that is ethically sourced. In 2007, ethically sourced coffee purchase accounts for 65 percent of corporate total coffee purchase [9]. In 2013, it jumped to 95 percent [9]. The company has set a 2015 target in order to ensure all of its coffee purchase is ethically sourced [9].

Global coffee market size and the total consumption of coffee have increased worldwide. Popularity of coffee has given coffee companies business chances to expand globally. By having the amount of purchased ethically sourced coffee divided by the amount of the world total coffee production, calculation of company A's purchase ratio becomes possible. This result implies the influential impact of the company A on the global coffee market. In 2013, company A's purchase amount of ethically sourced coffee accounts for approximately 2 percent of the total world coffee production, indicating its influence on the global coffee market [9], [19]. Over the years, coffee consumption has increased significantly [20]. Integrating environmental engagement into business strategies could also elevate the brand value and market share of the company.

The more purchase of this type of coffee in turn would increase (+) global total Arabica coffee production. The increase in global total Arabica coffee production would then further increases (+) the availability of Arabica coffee to the market, enabling a further purchase of environmental friendly Arabica coffee. The whole process creates a reinforcing loop (R) (Fig. 1).

\section{CONClusion}

This study uses company A as an example to analyze the impacts of business strategy on coffee production and the environment. Farmer loan support, as an environmental engagement strategy of company $\mathrm{A}$, is found to impact the decision-making processes of farmers, inducing the production shade-grown Arabica coffee. Integrating environmental sustainability into business strategies links to the stable supply of high-quality Arabica coffee. The strategy benefits both the company and the environment.

This study demonstrates that the establishment of a win-win relationship between the corporation and the environment is possible. The business model developed by company A could help to reduce deforestation, $\mathrm{CO}_{2}$ emissions, and climate change impacts. If all corporations 
that engage in coffee business integrate environmental sustainability into their business strategies, more farmers would be induced to produce shade-grown Arabica coffee that is healthier to the environment. In doing so, the overall social benefit would increase.

Coffee is one of three major beverage crops. Sustainable farming practices link to the health of the environment and the livelihood of people who depend on coffee production to support their families. To reduce the production of sun-grown Robusta coffee and to increase the production of environmental friendly shade-grown Arabica coffee, supports by consumers, farmers, corporations, and governments are essential. Besides corporate efforts, further research and policies that are more effective to induce the production of shade-grown Arabica coffee should be designed and analyzed.

\section{REFERENCES}

[1] IPCC. (2013). Climate change in 2013: The physical science basis. contribution of working group $i$ to the fifth assessment report of the intergovernmental panel on climate change. [Online]. Available: https://www.ipcc.ch/report/ar5/wg1/

[2] X. Li, T. Takahashi, N. Suzuki, and H. M. Kaiser, "The impacts of climate change maize yields in the United States and China," Agricultural Systems, vol. 104, pp. 348-353, 2011.

[3] X. Li and N. Suzuki, "Implications of climate change impacts on regional maize production in the United States: Risk mitigation strategies and food security," International Journal of Environmental Science and Development, vol. 4, pp. 446-451, 2013.

[4] C. Esteve, E. Manuel, and B. Katrina, "Reducing greenhouse gas emissions from deforestation and forest degradation in developing countries: revising the assumptions," Climate Change, vol. 100, pp. $355-388,2010$

[5] C. H. Gabriele and C. Ulrich, "Greenhouse gas induced climate change," Environmental Science and Pollution Research, vol. 3, pp. 99-102, 1996.

[6] H. Paeth, A. Hense, R. Glowienka-Hense, S. Voss, and U. Cubasch, "The North Atlantic Oscillation as an indicator for greenhouse-gas induced regional climate change," Climate Dynamics, vol. 15, pp. 953-960, 1999

[7] C. O. Stockle, P. T. Dyke, J. R. Williams, C. A. Jones, and N. J. Rosenberg, "A method for estimating the direct and climatic effects of rising atmospheric carbon dioxide on growth and yield of crops: part II-sensitivity analysis at three sites in the Midwestern USA," Agricultural Systems, vol. 38, pp. 239-256, 1992.

[8] FAO. (2014). FAOSTAT. [Online]. Available: http://faostat.fao.org/site/567/default.aspx\#ancor

[9] Starbucks. (2013). Global Responsibility Report Goals \& Progress. [Online]. http://www.starbucks.com/responsibility/global-report
[10] ICO. (2014). Botanical Aspects. [Online]. Available: http://www.ico.org/botanical.asp

[11] P. Opdam, G. Rijsdijk, and F. Hustings, "Bird communities in small woods in an agricultural landscape: Effects of area and isolation," Biological Conservation, vol. 34, pp. 333-352, 1985.

[12] R. Greenberg, P. Bichier, A. C. Angon, and R. Reitsma, "Bird populations in shade and sun coffee plantations in central Guatemala," Conservation Biology, vol. 11, pp. 448-459, 1997.

[13] S. A. Bhagwat, C. G. Kushalappa, P. H. Williams, and N. D. Brown, "A landscape approach to biodiversity conservation of sacred groves in the western ghats of India," Conservation Biology, vol. 19, pp. 1853-1862, 2005.

[14] S. Jha, C. M. Bacon, S. M. Philpott, V. E. Méndez, P. Läderach, and R. A. Rice, "Shade coffee: Update on a disappearing refuge for biodiversity," Bioscience, 2014.

[15] R. Borkhataria, J. A. Collazo, and A. Jordan-Garciab, "Shade-grown coffee in Puerto Rico: Opportunities to preserve biodiversity while reinvigorating a struggling agricultural commodity," Agriculture, Ecosystems and Environment, vol. 149, pp. 164-170, 2011.

[16] The University of Texas at Austin. (2014). Shade grown coffee shrinking as a proportion of global coffee production. [Online] Available:

http://www.utexas.edu/news/2014/04/16/shade-grown-coffee-shrinkin $\mathrm{g} /$

[17] S. L. M. Trærup and O. Mertz. "Rainfall variability and household coping strategies in northern Tanzania: a motivation for district-level strategies," Regional Environmental Change, vol. 11, pp. 471-481, 2010.

[18] SCS global services. (2014). Starbucks C.A.F.E. practices. [Online]. Available: http://www.scsglobalservices.com/starbucks-cafe-practices

[19] USDA. (2013). Coffee: World markets and trade. [Online]. Available: http://apps.fas.usda.gov/psdonline/circulars/coffee.pdf

[20] I. Perfecto, R. A. Rice, R. Greenberg, M. E.van der Voort, "Shade Coffee: A Disappearing Refuge for Biodiversity," BioScience, vol. 46, pp. 598-608, 1996.

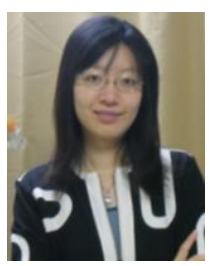

Xiang $\mathbf{L i}$ is an assistant professor at Chiba University, Japan, belonging to the Faculty of Law, Politics, and Economics. She teaches international policy courses. She graduated from the University of British Columbia, Canada with the bachelor degree of science for natural resources conservation in 2007. She received her science master degree in 2010 and Ph.D. degree in 2013 for International Environmental Economics at the University of Tokyo in Japan.

She was a DBA director at the Graduate School of International Corporate Strategy of Hitotsubashi University, a national University in Japan. She was an assistant professor at the Academy for Co-creative Education of Environment and Energy Science of Tokyo Institute of Technology, another national University in Japan.

Among Li's published refereed academic articles and issued patents, one that focused on climate change adaptation and mitigation strategy has been highlighted and introduced by Nature Climate Change Journal (Nature Publishing Group) in February 2011 